\title{
Treatment of Dye Effluent by Electrochemical and Biological Processes
}

\author{
Balakrishnan Ramesh Babu, Anand Kuber Parande*, Saravanan Arun Kumar, \\ Sirasanaganbla Udya Bhanu \\ Central Electrochemical Research Institute, Karaikudi, India \\ E-mail: "corrparande@yahoo.co.in
}

Received May 3, 2011; revised June 1, 2011; accepted June 7, 2011

\begin{abstract}
Textile dye wastewater is well known to contain strong colour, high $\mathrm{pH}$, temperature, Chemical Oxygen Demand (COD) and biodegradable materials. The electrochemical treatment of wastewater is considered as one of the advanced oxidation processes, potentially a powerful method of pollution control, offering high removal efficiencies the removal of colour of methyl red azo dye is a challenge in textile industry. The following methods have been adopted for the treatment of real textile wastewater: 1) Electro-oxidation (EO) and 2) Bio-treatment (BT). In EO process, reduction of COD and removal of colour were $70 \%$ and $81 \%$ respectively. The effluent was further treated by BT. BT showed a final reduction of $92 \%$ of COD and removal of colour by $95 \%$. Both the combined processes were highly competitive and showed a very good reduction of COD and colour removal. Electrochemical processes generally have lower temperature requirement than those of other equivalent non-electrochemical treatments and there is no need for additional chemicals. These treatment methods may also be employed successfully to treat other industrial effluents.
\end{abstract}

Keywords: Textile Wastewater, COD, Colour Removal, Electro Oxidation, Biological Process, FTIR

\section{Introduction}

Treatment of real textile wastewater (RTWW) has become a real challenge in recent years. The textile industry is one of the most important export industries of India. The RTW is notoriously known to have strong color, large amount of suspended solids (SS), broadly fluctuating $\mathrm{pH}$, high temperature, and high Chemical Oxygen Demand (COD) [1,2]. Different combinations of treatment methods have been proposed in order to be effective. Removal techniques for coloring substances include adsorption, precipitation; coagulation, filtration, and chemical oxidation have been studied by many researchers [1-5].

Biological methods are generally cheap, simple and easy to apply to remove organic compounds in the textile wastewater [6-8]. But the refractory pollutants present in the RTW cannot easily be degraded by traditional biological process with microorganisms $[9,10]$. It can be treated by some other methods to make the effluent as biodegradable.

The use of anaerobic digestion for the decolorisation of dyes has been investigated [11]. Textile dyes can rarely be aerobically degraded; azo dyes can be anaerobically reduced, producing colorless aromatic amines. In the first stage the dye is decolorized by the reduction of the azo bond through bacteria directly or indirectly under anaerobic conditions. In order to produce reduction equivalents that can be transferred to the dye molecule, an auxiliary substrate must be present that can be oxidized by the bacteria [12-15]. Large polar sulfonated dyes [16] such as reactive dyes are unlikely to diffuse through the cell membrane, so that extra cellular nonenzymatic redox mediators, e.g. chinones, play an important role in decolorization with whole cells [17].

Azo dyes are chemical compounds bearing the functional group $\mathrm{R}-\mathrm{N}=\mathrm{N}-\mathrm{RO}$ in which $\mathrm{R}$ and $\mathrm{RO}$ are aryl groups. Because of the electron delocalization through the $\mathrm{N}=\mathrm{N}$ group these compounds have vivid colors, such as red, orange, or yellow $[18,19]$. The colour is dependent on the chromophore and the extent of conjugation. Depending on the number of azo groups there are mono-, di- and tri-azo dyes. Azo dyes generally are bound to the textile fibres through secondary bonds. Reactive dyes contain different organic compounds which forms a chemical bond with textile fibers $[20,21]$. 
The electrochemical treatment of wastewater is considered as one of the advanced oxidation processes, potentially a powerful method of pollution control, offering high removal efficiencies. Electrochemical processes generally have lower temperature requirement than those of other equivalent non-electrochemical treatments and there is no need for additional chemicals. The required equipments and operations are simple. Their controls are easy and the electrochemical reactors are compact. It can also prevent the production of unwanted secondary sludge. The main oxidizing agent in electrochemical process is hypochlorite ion or hypochlorous acid generated produced from chloride ions.

Azo dyes constituting the largest class among the synthetic colors. The effective and economic performance of the process has been proven to be strongly dependent on electrode materials, and many researchers have investigated electrochemical oxidation for azo dye degradation through operating parameters optimization using various anodes including $\mathrm{RuO}_{2}, \mathrm{SnO}_{2}, \mathrm{PbO}_{2}$ and diamond electrode [22-25].

Nowadays, many combined processes are suggested. One of the studies reported that RTW was treated by the combined processes of chemical coagulation, electrochemical oxidation and activated sludge [26]. Ahn et al. [27] studied Fenton's oxidation and activated carbon adsorption as pretreatment processes for dyeing wastewater treatment. Nicolaou and Hadjivassilis [28] employed the combined process of chemical coagulation, activated sludge filtration and disinfection for textile wastewater treatment. The present study emphases a method for the removal of COD and colour from RTW contains methyl red azo dye by the application of EO and followed by BT.

\section{Materials and Method}

All the reagents used were of AR grade.

The azo dye used in this study was obtained from a textile-dyeing factory located in Tirupur, Tamil Nadu, India. The characteristic of RTWW is shown in Table 1. Biodegradation was carried out at a temperature of $25^{\circ} \mathrm{C}$ in $250 \mathrm{ml}$ flasks. Table 2 shows the composition of the Textile Wastewater (RTWW)

\subsection{Experimental Setup for EO Process}

The schematic diagram of the experimental setup given in Figure 1 consists of a glass beaker of $500 \mathrm{ml}$ capacity with PVC lid having provision to fit a cathode and an anode. Salt bridge with reference electrode was inserted through provided in the lid. Proper provisions were made in the lid for inserting of thermometer and for periodic
Table 1. Characteristics of textile wastewater.

\begin{tabular}{ccc}
\hline S.No. & Parameter & Range \\
\hline 1. & $\mathrm{pH}$ & 11.4 \\
2. & Temperature $\left({ }^{\circ} \mathrm{C}\right)$ & 32 \\
3. & $\mathrm{COD}(\mathrm{mg} / \mathrm{L})$ & 8060 \\
4. & Suspended solid $(\mathrm{mg} / \mathrm{L})$ & 270 \\
5. & Conductivity $(\mu \mathrm{mho} / \mathrm{cm})$ & 2800 \\
6. & Chlorides $(\mathrm{mg} / \mathrm{L})$ & 160 \\
\hline
\end{tabular}

Table 2. The composition of the Textile Waste water.

\begin{tabular}{ccc}
\hline S No & Water Characteristics : & Concentrations \\
\hline 1 & colour & Dark reddish orange \\
2 & turbidity & $1026 \mathrm{NTU}$ \\
3 & $\mathrm{pH}$ & 8.62 \\
4 & Chemical Oxygen Demand (COD) & $3145 \mathrm{mg} / \mathrm{L}$ \\
5 & Total Suspended Solids & 836 \\
6 & Conductivity & 4500 \\
7 & Dissolved Oxygen & $1.1 \mathrm{mg} / \mathrm{L}$ \\
\hline
\end{tabular}

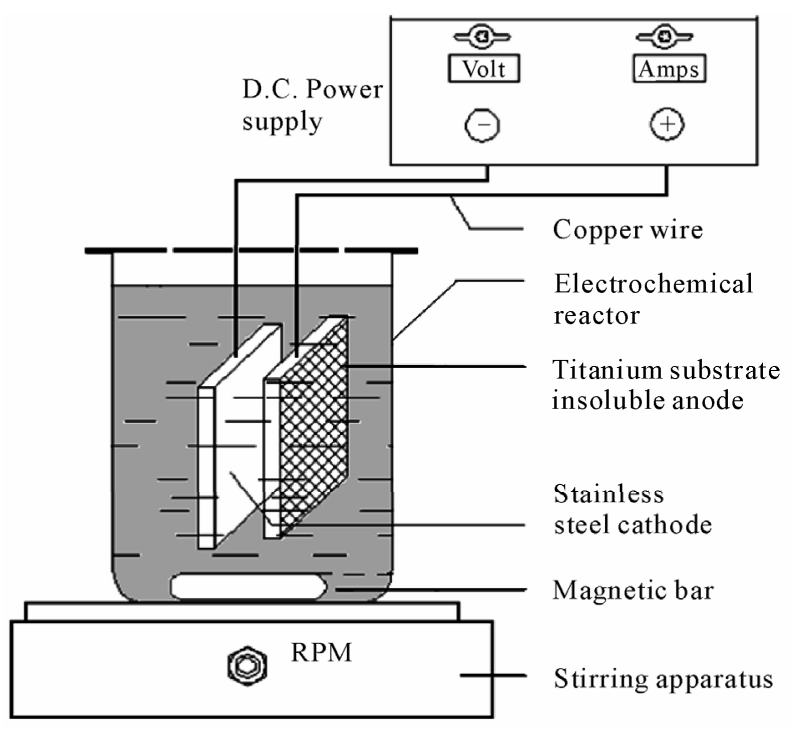

Figure 1. Schematic diagram of the experimental setup for EO process.

sampling. It comprises of an anode, a cathode and DC rectifier. The anode was made of mesh of titanium (12 $\mathrm{cm} \times 6 \mathrm{~cm})$ coated with $\mathrm{RuO}_{2}$, stainless steel $(12 \mathrm{~cm} \times 6$ $\mathrm{cm})$ was used as cathode. The distance between electrodes was $1.5 \mathrm{~cm}$. The applied current density was 2 $\mathrm{A} / \mathrm{dm}^{2}$ and $400 \mathrm{ml}$ of biologically treated combined dye house wastewater was taken in the glass beaker for further reduction of COD by electro oxidation. Experiments were carried out under galvanostatic conditions using a DC-regulated power source (HIL model 3161) of 0 - 2 A 
and $0-30 \mathrm{~V}$. Stirring was done with a magnetic stirrer. Electrolysis was carried out under batch mode. During these processes samples were collected at different time intervals and the COD was measured. Standard methods for examination of wastewater [29] were used for the estimation of COD and colour.

\subsection{Enumeration of Micro Organism}

The textile sample was serially diluted using $9 \mathrm{ml}$ distilled water blanks. The total viable counts were enumerated using nutrient agar medium by pour plate method [30]. Duplicate samples were tested along with control.

Total viable counts were made based on the following formulae:

$$
\mathrm{CFU} / \mathrm{cm}^{2}=\frac{\text { Average number of colony } \times 10 \mathrm{ml}}{\text { Dilution factor } \times \text { volume of sample added }}
$$

\subsection{Analytical Measurements}

FTIR and UV techniques were adopted for analysis of treated and untreated dye effluent by EO and BT.

\section{Results and Discussion}

\subsection{Electro-Oxidation Process}

Table 3 and Table 4 shows that values of reduction in COD as well as colour. About $70 \%$ of COD removal and $80 \%$ of colour removal was achieved by this method. The mechanism of electrooxidation is explained in Figure 2.

\subsection{Mechanism of Electro Oxidation}

In known that the organic compounds are completely oxidized to carbon dioxide. The electrode materials with high electro catalytic the complex organic compounds to its simple fragments than can be easily oxidized to carbon dioxide and water so as to split activity the organic compounds are degraded to $\mathrm{CO}_{2}$ and $\mathrm{H}_{2} \mathrm{O}$.

In case of $\mathrm{EO}, \mathrm{OH}$, generated electrochemically by splitting of $\mathrm{H}_{2} \mathrm{O}$, gets discharged at the anode resulting in radical $(\mathrm{OH})$ as shown in Equation (1)

$$
\mathrm{RuO}_{2}+\mathrm{H}_{2} \mathrm{O} \rightarrow \mathrm{RuO}_{2}(\cdot \mathrm{OH})+\mathrm{H}^{+}+\mathrm{e}^{-}
$$

Later, the $\left({ }^{\circ} \mathrm{OH}\right)$ radical, gets adsorbed on to the $\mathrm{RuO}_{2}$ forming a complex of the type $\left(\mathrm{RuO}_{2}\left({ }^{\circ} \mathrm{OH}\right)\right)$ which inturn gets converted to $\left(\mathrm{RuO}_{2}(\mathrm{O})\right)$ of higher oxidation state.

$$
\mathrm{RuO}_{2}+(\cdot \mathrm{OH}) \rightarrow \mathrm{RuO}_{2}\left({ }^{*} \mathrm{O}\right)+\mathrm{H}^{+}+\mathrm{e}^{-}
$$

Thus both physisorbed $\left(\mathrm{RuO}_{2}\left({ }^{\circ} \mathrm{OH}\right)\right)$ active oxygen and
Table 3. Effect of current density on the treatment of effluent by electro-oxidation process.

\begin{tabular}{c|cccc}
\hline \multirow{2}{*}{$\begin{array}{c}\text { Initial COD } \\
(\mathrm{mg} / \mathrm{l})\end{array}$} & \multicolumn{4}{|c}{ Final COD (mg/l) (5 hours) } \\
\cline { 2 - 5 } & 1 & \multicolumn{4}{|c}{ Current density $\left(\mathrm{A} / \mathrm{dm}^{2}\right)$} \\
\hline \multirow{2yyyy}{*}{8060} & 2805 & 2964 & 2430 & 2458 \\
\hline
\end{tabular}

\begin{tabular}{|c|c|c|c|c|}
\hline \multirow{2}{*}{$\begin{array}{l}\text { Name of the } \\
\text { Organism }\end{array}$} & \multicolumn{2}{|c|}{$\begin{array}{l}\text { Biological Treatment } \\
\text { COD (mg/l) }\end{array}$} & \multirow{2}{*}{$\begin{array}{l}\% \text { Reduction } \\
\text { of COD }\end{array}$} & \multirow{2}{*}{$\begin{array}{c}\% \text { Reduction } \\
\text { of colour } \\
\text { removal }\end{array}$} \\
\hline & Initial & $\begin{array}{c}\text { Final } \\
\text { (5 days) }\end{array}$ & & \\
\hline $\begin{array}{l}\text { Pseudomonas } \\
\text { putida }\end{array}$ & 2430 & 215 & 91.15 & 95.23 \\
\hline $\begin{array}{l}\text { Phanerochaete } \\
\text { chrysosporium }\end{array}$ & 2430 & 350 & 85.59 & 93.02 \\
\hline $\begin{array}{l}\text { Bacillus } \\
\text { cereus }\end{array}$ & 2430 & 455 & 81.27 & 90.27 \\
\hline $\begin{array}{l}\text { Tricoderma } \\
\text { virdae }\end{array}$ & 2430 & 540 & 77.77 & 85.16 \\
\hline
\end{tabular}

Table 4. Treatment of textile effluent by Biological Treatment method.

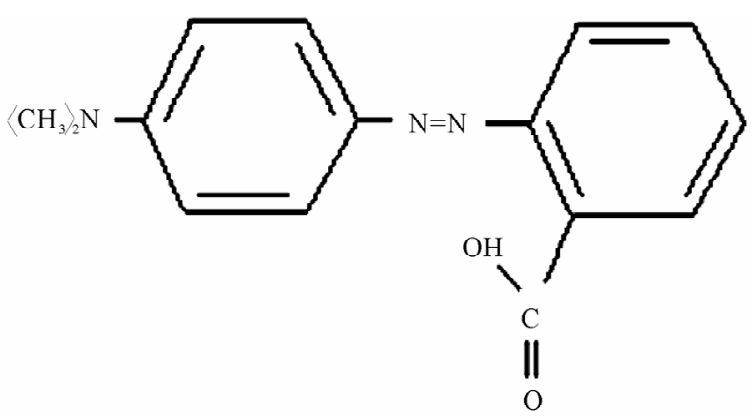

Figure 2. Structure of Methyl red azo dye.

chemisorbed $\left(\mathrm{RuO}_{2}\left({ }^{\circ} \mathrm{O}\right)\right)$ active oxygen release diatomicoxygen. It can be considered that at the anode surface two states of "active oxygen" can be presented:

$$
\begin{gathered}
\mathrm{RuO}_{2}(\cdot \mathrm{OH}) \rightarrow 1 / 2 \mathrm{O}_{2}+\mathrm{H}^{+}+\mathrm{e}^{-}+\mathrm{RuO}_{2} \\
\mathrm{RuO}_{2}\left({ }^{*} \mathrm{O}\right) \rightarrow \mathrm{RuO}_{2}+1 / 2 \mathrm{O}_{2}
\end{gathered}
$$

It may be speculated in this case that physisorbed active oxygen predominantly oxidized the organics and chemisorbed oxygen $\mathrm{RuO}_{2}\left({ }^{\circ} \mathrm{O}\right)$ decides the fate of the intermediate product.

\subsection{Biological Process}

More than 20 microbes were isolated from the textile wastewater. Four microbes namely Pseudomonas, phanerochaete, Bacillus and tricoderma were used in this 
study. The microbes culture were cultivated in a fermenter containing sterilized media, nutrient broth, and utilized to inoculate into wastewater. The COD reduction by the biological treatment was carried out. Table 3 shows COD removal efficiency. At the end of $5^{\text {th }}$ day, Pseudomonas putida gives the maximum reduction of COD as $92 \%$ and colour removal as $95 \%$ respectively.

\subsection{Mechanism of Pseudomonas Putida in Treatment}

Among the microbes, the addition of Pseudomonas putida into the RTWW gave the best performance in the reduction of COD. Aromatic compounds are susceptible to biological degradation in both aerobic and anaerobic conditions. Diazo bond in azo dyes could be parted by azo reductive enzyme produced by Pseudomonas putida in anoxic or anaerobic condition, and then an azo dye molecule was made of two amine molecules holding $-\mathrm{NH}_{2}[31]$.

$$
\mathrm{R}_{1}-\mathrm{N}=\mathrm{N}-\mathrm{R}_{2}+4 \mathrm{e}^{-}+4 \mathrm{H}^{+} \rightarrow \mathrm{R}_{1}-\mathrm{NH}_{2}+\mathrm{R}_{2}-\mathrm{NH}_{2}
$$

where $R_{1}$ and $R_{2}$ were various phenol and naphthol residues. Then after, amine could be decomposed by ammonia by an action of hydrogenation enzyme and hydrolysis enzyme in anoxic condition [32]. From the study it is concluded that by the action of hydrolysis microbes, azo in raw waste water produced organic amine and $\mathrm{NH}_{3}$ and these product solutions were alkaline, the quantities of organic amine and $\mathrm{NH}_{3}$ augmented gradually.

\subsection{Mechanism of Azo Dye Reduction}

The very first step in the bacterial degradation of azo dyes, in both the anaerobic or aerobic conditions, is the reduction of the $-\mathrm{N}=\mathrm{N}-$ bond. This reduction might be involving different mechanisms. For example the reactions of the enzymes, low molecular weight redox mediators, chemical reduction by biogenic reductants like sulfide or a combination which is shown in the Figure 3. Additionally, the location of the reactions can be either intracellular or extracellular depending on the availability of the active microbial species.

Microorganisms, bacteria, with their enzyme systems degrade the aromatic structure under aerobic and anoxic conditions [33-34]. However, in both the conditions, microbes metabolize aromatic compounds in both the peripheral and central path-ways of the cell [35]. Peripheral pathways convert a wide variety of compounds into a few intermediate products or fragments. In aerobic metabolism, the initial reactions involve the replacement of other functional groups attached to the aromatic ring with hydroxyl groups, followed by cleavage by involving

\section{Direct enzymatic}

Indirect (mediated biological)
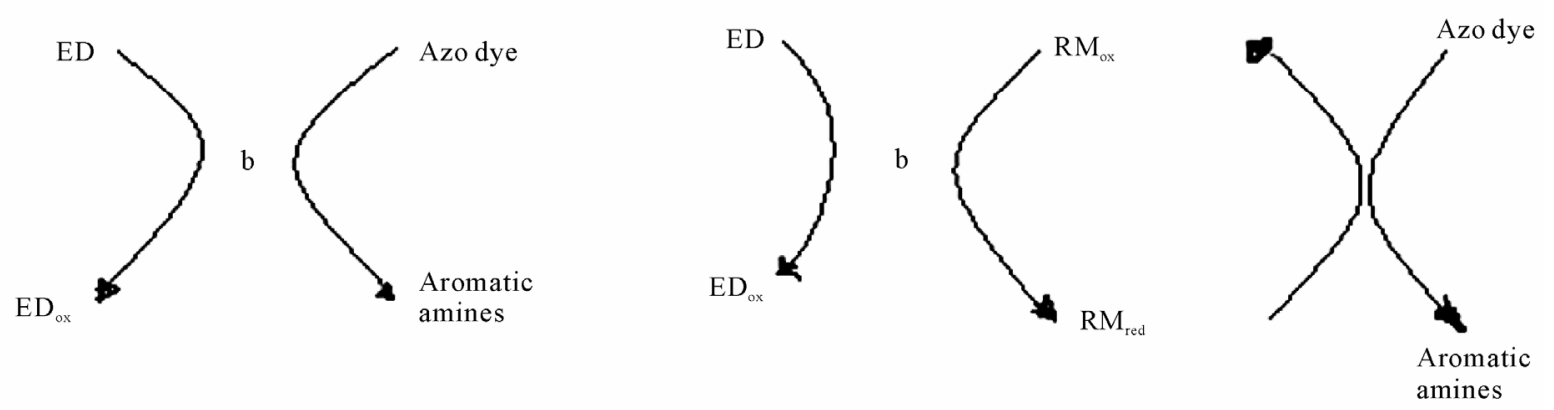

Direct chemical

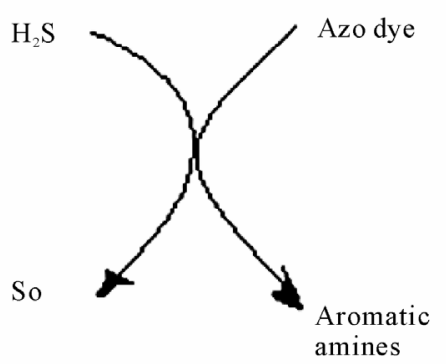

Figure 3. Schematic representation of different mechanisms of anaerobic azo dye reduction. $\mathrm{RM}=$ Redox mediator; $\mathrm{ED}=$ electron donor; $b$ = bacteria(enzymes). 
two oxygen atoms. These reactions are catalysed by enxymes like hydroxylases and oxygenases. Under anoxic conditions ring reduction and other unique reactions such as carboxylation, reductive dehydroxylation, addition reactions etc are predominant which are absent in the aerobic metabolism [35].

The trend of the microorganism in removal of COD and colour is as follows:

Pseudomonas $>$ phanerochaete $>$ Bacillus $>$ Tricoderma.

\subsection{FTIR Analysis of the Sample}

The sample was given for FTIR spectrum analysis before and after treatment. Figure 4 shows the FTIR spectra of untreated and treated by electrooxidation and biological method dye effluent. Major peaks were obtained for untreated sample at 3302.08, 2107.55, 1636.47 and 709.29 $\mathrm{cm}^{-1}$ shown in Figure 4(a). The absorbance of peaks at $3302.03 \mathrm{~cm}^{-1}$ and $1636.47 \mathrm{~cm}^{-1}$ were due to the structural vibration of hydrogen in bound with $\mathrm{OH}$ groups of phenol or $\mathrm{OH}$ of carboxyl groups $\mathrm{COOH}$ and the hydrogen vibration of amide N-H functions. It shows that the sample contain high content of water molecule and considerable amount of alkanes $(\mathrm{C}-\mathrm{H})$. After decolourization showed absence of peak at $1600 \mathrm{~cm}^{-1}$ indicates breakdown of azo bond, might be due to action of azo reductase. Absence of peaks at $688 \mathrm{~cm}^{-1}, 726 \mathrm{~cm}^{-1}, 765 \mathrm{~cm}^{-1}$ and $827 \mathrm{~cm}^{-1}$ indicates loss of aromatic or benzene ring.

The absorbance of peaks at $2107.99 \mathrm{~cm}^{-1}$ was due to the vibration of $\mathrm{C}=\mathrm{O}$ and intense absorbance of the bands at $1620-1640$ and $1510-1540 \mathrm{~cm}^{-1}$ was also observed, indicating enrichment in amide and aromatic. The appearance of peak at $1636.47 \mathrm{~cm}^{-1}$ indicates the pressure of $\mathrm{C}=\mathrm{C}$ conjugated diene groups. This is due to the functional group of aromatic carbons. The absorbance of peaks at $709.23 \mathrm{~cm}^{-1}$ (out-of plane bending modes of aromatic $\mathrm{C}-\mathrm{H}$ bonds) was found to be due to the vibration of aromatic compounds and benzene ring. Figure 4(b) shows the FTIR spectra of treated sample by Electro-Oxidation. After the EO method, decolourization showed absence of peak at $1636.47 \mathrm{~cm}^{-1}$ indicates breakdown of aromatic rings. Peak at $1615 \mathrm{~cm}^{-1}$ indicates synthesis of aliphatic secondary amines and dimethyl groups it seems that azo reductase catalyses the reductive cleavage of the azo bond of methyl red [36]. Figure 4(c) shows the FTIR spectra of biologically treated sample. Out of the four organisms used Pseudomonas putida showed the best performance which degrades to facilitate by oxidative enzymes.

\subsection{UV}

The samples were given for UV-Vis spectra analysis before treatment and after EO treatment and BT treatment and are shown in Figure 5. The intensity of peaks was reduced by EO and is shown in Figure 5(b) and followed by BT method Figure 5(c). The dye UV spectrum before treatment exhibited absorption bands at 545 $\mathrm{nm}$. The characteristic band at 485 to $570 \mathrm{~nm}$ could be assigned to the $n-\pi *$ transition of $-\mathrm{N}=\mathrm{N}-$ group [37]. The weak band below $350 \mathrm{~nm}$ could be attributed to the $\pi-\pi^{*}$ transition related to the aromatic ring attached to the $-\mathrm{N}=\mathrm{N}-$ group in the dye molecule. It is apparent that the intensity of characteristic band $(545 \mathrm{~nm})$ of dye solution was found to diminish gradually during the experiment and disappeared totally after EO and BT. The disappearance of the bands indicates the effective destruction of the azo. The intensity of the absorption spectra was reduced further by BT as it is evident from Figure 5(b) when compared with EO treatment shown in Figure 5(c). It could be concluded that the dye molecule undergoes degradation in the presence of microorganisms. This clearly indicates that the intensity of the absorption spec-

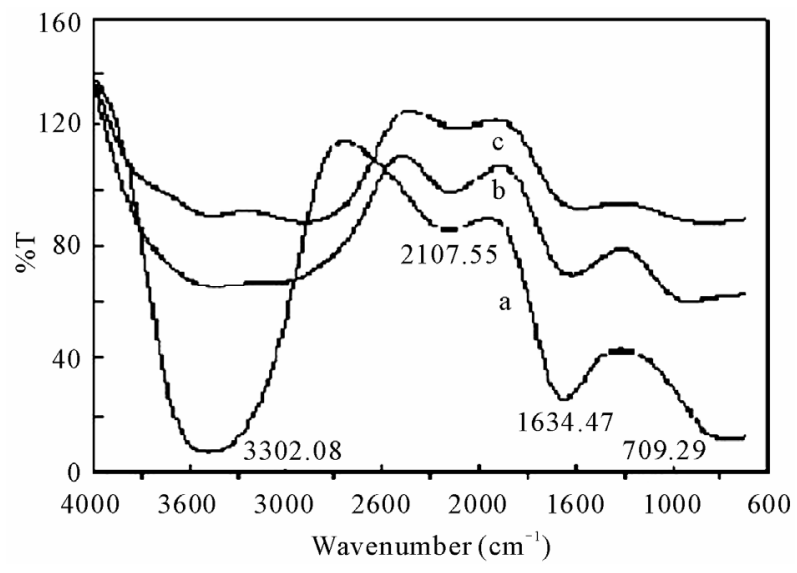

Figure 4. FTIR spectra of untreated dye effluent (a), electro-oxidation (b) and biologically treated (c).

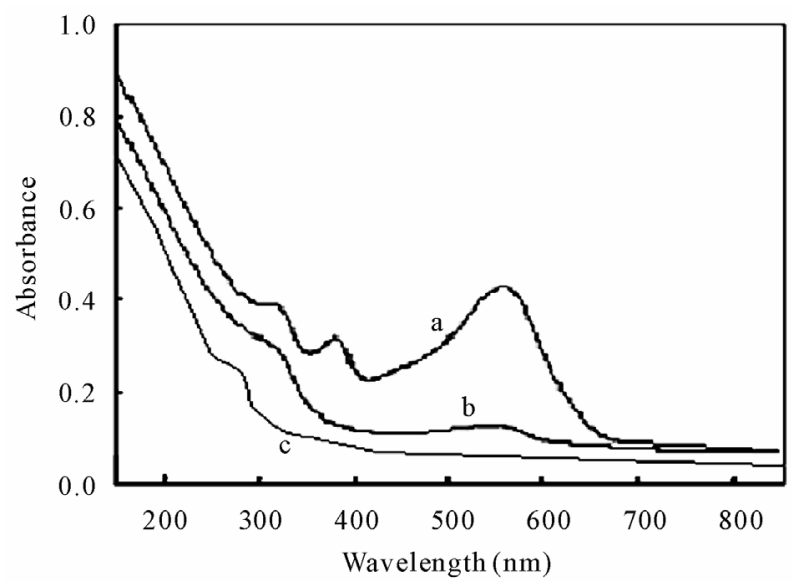

Figure 5. UV-vis spectra of untreated dye effluent (a), electro oxidation (b) and biologically treated (c). 
tra was reduced drastically after the combined effect of both the treatments.

\section{Conclusions}

The following conclusions were drawn:

1) COD and colour were reduced significantly by electrooxidation followed by biological method and the maximum were obtained as $91 \%$ and $95 \%$ respectively.

2) Pseudomonas putida showed the best bacteria for the reduction of COD and colour.

3) The performance of colour removal was significantly improved by the application of the combined treatment methods which was observed in UV studies.

4) FTIR reveals that aromatic compounds degraded to aliphatic compounds which are easily biodegradable.

5) The treated water can be reused for effective dyeing process.

6) The intensity of UV-Vis spectra was reduced drastically that clearly indicates azo dye degradation with electro-oxidation followed by biological treatment.

\section{References}

[1] L. D. Benefield, F. Judkins and B. L. Weand, "Process Chemistry for Water and Wastewater Treatment," Prentice-Hall, Upper Saddle River, 1982, pp. 365-404.

[2] W. Chu, "Dye Removal from Textile Dye Wastewater Using Recycled Alum Sludge," Water Research, Vol. 35, No. 13, 2001, pp. 3147-3152. doi:10.1016/S0043-1354(01)00015-X

[3] M. S. El-Geundi, "Colour Removal from Textile Effluents by Adsorption Techniques," Water Research, Vol. 25, No. 3, 1991, pp. 271-273. doi:10.1016/0043-1354(91)90006-C

[4] P. Janos, H. Buchtova and M. Ryznarova, "Sorption of Dyes from Aqueous Solutions onto Fly Ash," Water Research, Vol. 37, No. 20, 2003, pp. 4938-4944. doi:10.1016/j.watres.2003.08.011

[5] V. Meshko, L. Marrkovska, M. Mincheva, A. E. Rodrigues, "Adsorption of Basic Dyes on Granular Activated Carbon and Natural Zeolite," Water Research, Vol. 35, No. 14, 2001, pp. 3357-3366. doi:10.1016/S0043-1354(01)00056-2

[6] Society of Dyes and Colourists, "Color Index," Vol. 8, the Society of Dyes and Colourists, the American Association of Textile Chemists and Colorists, 3rd Edition, Supplement to Vol. 1-4, 6 and 7, Society of Dyes and Colourists, Bradford, 1971.

[7] I. K. Kapdan and F. Kargi, "Simultaneous Biodegradation and Adsorption of Textile Dyestuff in an Activated Sludge Uni," Process Biochemistry, Vol. 37, No. 9, 2002, pp. 973-981. doi:10.1016/S0032-9592(01)00309-0

[8] P. Nigam, I. M. Banat, D. Singh and R. Marchant, "Microbial Process for the Decolorization Of Textile Effluent Containing Azo, Diazo and Reactive Dyes," Process Bio- chemistry, Vol. 31, No. 5, 1995, pp. 435-442. doi:10.1016/0032-9592(95)00085-2

[9] I. Kapdan, F. Kargi, G. McMullan and R. Marchant, "Comparison of White-Rot Fungi Cultures for Decolorization of Textile Dyestuff," Bioprocess Engineering, Vol. 22, No. 4, 2000, pp. 347-351. doi: $10.1007 / \mathrm{s} 004490050742$

[10] L. C. Chiang, J. E. Chang and S. C. Tseng, "Electrochemical Oxidation Pretreatment of Refractory Organic Pollutants," Water Science Technology, Vol. 36, No. 2-3, 1997, pp. 123-130. doi:10.1016/S0273-1223(97)00378-8

[11] B. Donlon, E. Razo-Flores, M. Luijten, H. Swarts and G. Let tinga and J. Field, "Detoxification and Partial Mineralization of the Azo Dye Mordant Orange 1 in a Continuous Upflow Anaerobic Sludge-Blanket Reactor," Applied Microbiol Biotechnology, Vol. 47, No. 1, 1997, pp. 83-90. doi:10.1007/s002530050893

[12] R. Minke and U. Rott, "Anaerobic Treatment of Split Flow Wastewater and Concentrates from the Textile Processing Industry," Water Science Technology, Vol. 40, No. 1, 1999, pp. 169-176.

doi:10.1016/S0273-1223(99)00377-7

[13] F. Sosath and J. A. Libra, "Biologische Behandlung von Synthetischen Abwässern mit Azofarbstoffen, "Acta Hydrochimica Hydrobiology, Vol. 25, 1997, pp. 259-264. doi:10.1002/aheh.19970250506

[14] A. Stolz, "Basic and Applied Aspects in the Microbial Degradation of Azo Dyes," Applied Microbiology Biotechnology, Vol. 56, No. 1-2, 2001, pp. 69-80. doi:10.1007/s002530100686

[15] E. S. Yoo, J. Libra and L. Adrian, "Mechanism of Decolorization of Azo Dyes in Anaerobic Mixed Culture," Journal of Environmental Engineering, Vol. 127, No. 9, 2001, pp. 844-849. doi:10.1061/(ASCE)0733-9372(2001)127:9(844)

[16] M. Kudlich, P. L. Bishop, H. J. Knackmuss and A. Stolz, "Simultaneous Anaerobic and Aerobic Degradation of the Sulfonated Azo Dye Mordant Yellow 3 by Immobilized Cells from a Naphatlenesulfonate-Degrading Mixed Culture," Applied Microbiol Biotechnology, Vol. 46, 1996, pp. 597-603. doi:10.1007/s002530050867

[17] A. Keck, J. Klein, M. Kudlich, A. Stolz, H. J. Knackmuss and R. Mattes, "Reduction of Azo Dyes by Redox Mediators Originating in the Naphthalenesulfonic Acid Degradation of Sphingomonas sp. Strain BN6," Applied Environmental Microbiology, Vol. 63, 1997, pp. 36843690 .

[18] S. Padmaja and S. A. Madison, "Hydroxyl Radical-Induced Oxidation of Azo Dyes: A Pulse Radiolysis Study," Journal of Physical Organic Chemistry, Vol. 12, No. 3, 1999, pp. 221-226. doi:10.1002/(SICI)1099-1395(199903)12:3<221::AID-P OC119>3.0.CO;2-U

[19] K. K. Sharma, B. S. Rao, M. Mohan, H. Mittal, J. P. Oakes, P. O’Neill, "P Free-Radical-Induced Oxidation and Reduction of 1-Arylazo-2-Naphthol Dyes: A Radiation Chemical Study," Journal of Physical Chemistry A, Vol. 106, No. 12, 2002, pp. 2915-2923. 


\section{doi:10.1021/jp014025b}

[20] K. K. Sharma, P. O’Neill, J. Oakes, S. N. Batchelor, B. S. M. Rao, "One-Electron Oxidation and Reduction of Different Tautomeric Forms of Azo Dyes: A Pulse Radiolysis Study," Journal of Physical Chemistry A, Vol. 107, No. 38, 2003, pp. 7619-7628. doi:10.1021/jp035002v

[21] K. Vinogdopal and V. P. Kamat, "Hydroxyl-Radical-Mediated Oxidation: A Common Pathway in the Photocatalytic, Radiolytic, and Sonolytic Degradation of Textile Dyes," In: W. J. Cooper, R. D. Curry, K. E. O’Shea, Eds., Environmental Applications of Ionizing Radiation, Wiley, New York, 1998, pp. 588-599.

[22] N. Mohan, N. Balasubramanian and V. Subramanian, "Electrochemical Treatment of Simulated Textile Effluent," Chemical Engineering Technology, Vol. 24, No. 7, 2001, pp. 749-753. doi:10.1002/1521-4125(200107)24:7<749::AID-CEAT74 9>3.0.CO;2-Y

[23] N. Mohan and N. Balasubramanian, "In Situ Electrocatalytic Oxidation of Acid Violet 12 Dye Effluent," Journal of Hazardous Materials, Vol. 136, No. 2, 2006, pp. 239-243. doi:10.1016/j.jhazmat.2005.11.074

[24] H. S. Awad and N. A. Galwa, "Electrochemical Degradation of Acid Blue and Basic Brown Dyes on $\mathrm{Pb} / \mathrm{Pbo}_{2}$ Electrode in the Presence of Different Conductive Electrolyte and Effect of Various Operating Factors," Chemosphere, Vol. 61, No. 9, 2005, pp. 1327-1335. doi:10.1016/j.chemosphere.2005.03.054

[25] X. M. Chen, G. H. Chen and P. L. Yue, "Anodic Oxidation of Dyes at Novel Ti/B-Diamond Electrodes," Chemical Engineering Science, Vol. 58, No. 3, 2003, pp. 995-1001. doi:10.1016/S0009-2509(02)00640-1

[26] A. G. Vlyssides and C. J. Israilides, "Electrochemical Oxidation of A Textile Dye and Finishing Wastewater Using Pt/Ti Electrode," Journal of Environmental Science Health A, Vol. 33, No. 5, 1998, pp. 847-862. doi:10.1080/10934529809376765

[27] D. H. Ahn, W. S. Chang and T. I. Yoon, "Dyestuff Wastewater Treatment Using Chemical Oxidation, Physical Adsorption and Fixed Bed Biofilm Process," Process Biochemistry, Vol. 34, No. 5, 1999, pp. 429-439. doi:10.1016/S0032-9592(98)00111-3
[28] M. Nicolaou and I. Hadjivassilis, "Treatment of Wastewater from the Textile Industry," Water Science Technology, Vol. 25, No. 1, 1992, pp. 31-35.

[29] APHA, AWWA and WEF, "Standard Methods for Examination of Water and Wastewater," 19th Edition, Washington DC, 1995.

[30] C. O. Neill, F. R. Hawkes, D. L. Hawkes, S. Esteves and S. J. Wilcox, "Anaerobic/Aerobic Biotreatment of Simulated Textile Effluent Containing Varied Ratios of Starch and Azo Dye," Water Research, Vol. 34, No. 8, 2000, pp. 2355-2361. doi:10.1016/S0043-1354(99)00395-4

[31] P. Canizares, A. Gadri, J. Lobato, B. Nasr, R. Paz, M. A. Modrigo and C. Saez, "Electrochemical Treatment of the Pollutants Generated in an Ink-Manufacturing Process," Journal of Hazardous materials, Vol. 146, No. 3, 2007, pp. 552-557. doi:10.1016/j.jhazmat.2007.04.085

[32] K.-C. Chen, J.-Y. Wu, C.-C. Huang, Y.-M. Liang, S.-C. J. Hwang, "Decolorization of Azo Dye Using Pva-Immobilized Microorganisms," Biotechnology, Vol. 101, No. 3, 2003, pp. 241-252. doi:10.1016/S0168-1656(02)00362-0

[33] D. T. Gibson and V. Subramanian, "Microbial Degradation of Aromatic Hydrocarbons," In: D.T. Gibson, Ed., Microbial Degradation of Organic Compounds, Marcel Dekker, New York, 1984, pp. 181-252.

[34] B. Schink, B. Philipp and J. Muller, "Anaerobic Degradation of Phenolic Compounds, Review," Naturwissenschaften, Vol. 87, No. 1, 2000, pp. 12-23. doi:10.1007/s001140050002

[35] J. Heider and G. Fuchs, "Anaerobic Metabolism of Aromatic Compounds," European Journal of Biochemistry, Vol. 243, No. 3, 1997, pp. 577-596. doi:10.1111/j.1432-1033.1997.00577.x

[36] A. Moutaouakki, Y. Zeroula, F. Z. Dzayri, M. Talbi, K. Lee and M. Balgane, "Bacterial Decolourization of the Azo Dye Methyl Red by Enterobacter Agglomerans," Analytical Microbiology, Vol. 53, 2003, pp. 161-169.

[37] E. G. Solozhenko, N. M. Soboleva and V. V. Goncharuk, "Discoloration of Azo Dye Solutions by Fenton'S Oxidation," Water Res journal, Vol. 29, No. 9, 1991, pp. 2206-2210. 